\title{
PRODUKTIWITEITSVERHOGING: 'N BESTUURSWETENSKAPLIKE EN PRINSIPIËLE BESKOUING
}

\author{
S. Kruger \\ Dept. Ondernemingsbestuur \\ Randse Afrikaanse Universiteit \\ JOHANNESBURG
}

\begin{abstract}
The pursuit of high productivity is not a goal in itself, but rather regulates the attempt to raise a country's standard of living. Since the standard of living is dependent on the relationship between the total output and input of all businesses, the productivity of a single business has a great influence.

Increasing productivity is considered to be an extremely important management function. If productivity is regarded as the measuring instrument for successful management, then the management process and, more specifically, management by objectives is the method for achieving this.

It is management's responsibility to create the necessany climate for productivity and increased productivity. The approach must be one which achieves a balance between task-orientation and people-orientation.

Consequently the purpose and meaning of work should also be reconsidered. Work is not a goal in itself, but must always be seen within the wider context of God's cultural mandate to man. When everyone understands the meaning of work we will emerge from the so-called 'reward psychosis', and reward will be offered according to need and achievement. Reward and work fulfilment will lead to the creation of a work environment which is meaningful for the worker, which promotes increased productivity, and which allows self-actualization to flourish. Management is capable of creating and maintaining these circumstances which will increase productivity.
\end{abstract}

\section{INLEIDING}

Die strewe na hoë produktiwiteit is nie 'n einddoel op sigself nie, maar veel eerder die poging om die welvaartspeil van ' $n$ land te verhoog. Aangesien die welvaartspeil van'n land afhanklik is van die verhouding tussen totale uitset en totale inset van alle bedrywe, het die produktiwiteit van 'n enkele bedryf ' $n$ groot invloed, veral as die getal groot sakeondernemings in gedagte gehou word.

Produktiwiteit is onder meer die resultaat van 'n geestesinstelling van toekomsgerigt- 


\section{Produktiwiteitsverhoging: 'n bestuurswetenskaplike en prinsipiële beskouing}

heid en geloof in vooruitgang. Die ontwikkeling van 'n onderneming, 'n gemeenskap, 'n volk of 'n mens is ook 'n produk van menslike geloof en die wil om dit wat as waardevol beskou word, te verwesenlik. Miskien moet daar meer dikwels aan die mens in sy totaliteit as deel van 'n produksieproses gedink word, en aan dit wat sy arbeid en strewe sinvol maak. Miskien moet daar gedink word aan arbeid as skeppingsopdrag en kultuuropdrag want, word dié opdrag verwaarloos, lei dit onvermydelik tot die verval van die individu en die gemeenskap.

Wanneer gesoek word na die arbeidsaamheid tot heil van die mens, dan word die industriële geestesgesondheid in die wydste betekenis van die woord 'n maatstaf in sy eie reg, eerder as ' $n$ invloed op die produksiekriterium. Dit sou dus ook moontlik wees om selfs vir die mees skeptiese realis die produktiwiteitswaarde en 'goeie' besigheid van geestesgesondheid oortuigend te demonstreer. As voorbeeld kan in hierdie besondere geval genoem word dat by wyse van ' $n$ induksieprogram, spanning en angs onder nuwe werkers verwyder of selfs geminimaliseer kan word, opleidingstyd met selfs die helfte verkort kan word, en opleidingskoste met sowat 'n derde verminder kan word. Al hierdie sake behoort normaalweg 'n gunstige effek op produksie en produksiekoste te hê.

Produktiwiteitsverhoging word allerweë beskou as 'n uiters belangrike bestuurstaak. Indien produktiwiteit beskou word as die meetinstrument vir bestuursukses, dan is 'n doeltreffender bestuursproses die manier om daardie sukses te verwesenlik. Dit impliseer dat bestuur onder andere doelwitbestuur as bestuurstegniek kan gebruik om produktiwiteitsverbetering te bewerkstellig. Die oogmerk is nie net daarop ingestel om uitset te verhoog nie; dikwels is die oogmerk om 'n konstante uitset te bewerkstellig, afhangende van die aanvraag na die bepaalde uitset. Produktiwiteit begin by doelmatige en gebalanseerde bestuur (Ranft1, 1986:11).

Dit is bestuur se verantwoordelikheid om die klimaat vir produktiwiteit en produktiwiteitsverhoging te skep. Die benadering moet een van balans tussen taak- en mensoriëntasie wees. Daar is vandag nog diegene wat die mening huldig dat hoër produktiwiteit slegs bereik kan word deur groter fisiese inspanning. Hierdie aanname is van alle waarheid ontbloot. Toename in produktiwiteit verg veel meer as die blote toepassing van bestuurstegnieke.

Hierdie artikel bevraagteken die feit dat sakeleiers grotendeels konsentreer op die tegniek, eerder as om te werk in die rigting van gebalanseerde taak- en mensoriëntasie. Bedryfsleiers moet besef dat die werker se begeerte om produktiwiteit te verhoog van groot belang is.

Die primêre doel van hierdie artikel is om aan te toon dat produktiwiteitsverhoging 
alleen bewerkstellig kan word deur die totale betrokkenheid van bestuur.

\section{DEFINISIE EN BREëR BETEKENIS VAN PRODUKTIWTTEIT}

Ten einde die begrip produktiwiteit volledig toe te lig, word 'n kort verklaring van die begrippe doeltreffendheid en effektiwiteit gegee. Schemerhorn (1986:16) sê in dié verband:

Two criteria measure a manager's success in the quest for productivity and personal competen-

cy: performance effectiveness and performance efficiency.

Effektiwiteit impliseer die bereiking van 'n gewenste doel - die regte taak word afgehandel onafhanklik van die metodes of tegnieke wat ingespan is om dit te bereik. Doeltreffendheid impliseer dat die regte tegniek gevolg is om 'n taak af te handel of 'n doel te bereik. In dié geval sluit doeltreffendheid ook doelmatigheid in (om dinge reg te doen). 'n Konnotasie van tevredenheid word dan aan die begrip doeltreffendheid gegee (Van Niekerk, 1981:8). Doeltreffendheid is deurslaggewend vir die sukses van die onderneming. Figuur 1 stel sodanige bestuursukses voor:

Figuur 1

Die area van werklike bestuursukses

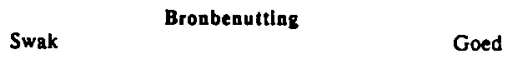

\begin{tabular}{l|l|l|}
\hline Hoog & $\begin{array}{l}\text { Doeltreffend, maar nie effektief nie. } \\
\text { Vermorsing van bronne. }\end{array}$ & $\begin{array}{l}\text { Doeltreffend en effektief. Doelstellings en } \\
\text { doeliwitte bereik. Bronne optimaal benut. Hoë } \\
\text { produktiwiteit }\end{array}$ \\
\hline $\begin{array}{l}\text { Doelstelling en } \\
\text { doelwitbereiking }\end{array}$ & $\begin{array}{l}\text { Ondoeltreffend, nie effektief nie. Doel- } \\
\text { stellings en doelwitte nie bereik nie. } \\
\text { Bronne vermors. }\end{array}$ & $\begin{array}{l}\text { Doeltreffend maar nie effektief nie. Bronne } \\
\text { goed aangewend. Doelstellings en doelwitte } \\
\text { nae bereik nie. }\end{array}$ \\
\hline
\end{tabular}

Area van werklike bestuursukses

Bron: Schemerhorn (1986:18). 
Dit is duidelik dat wanneer daar na figuur 1 se uiteensetting gekyk word, dit gaan om die optimum benutting van die produksiefaktore, arbeid, kapitaal, grondstowwe, kundigheid en tegnologie ten einde rentabiliteit van die onderneming oor die lang termyn te maksimeer.

In aansluiting by figuur 1 en die uiteensetting rondom effektiwiteit en doeltreffendheid, weerspieël figuur 2 die produktiwiteitsproses in meer eenvoudige terme.

\section{Figuur 2}

\section{Die produktiwiteitsproses}

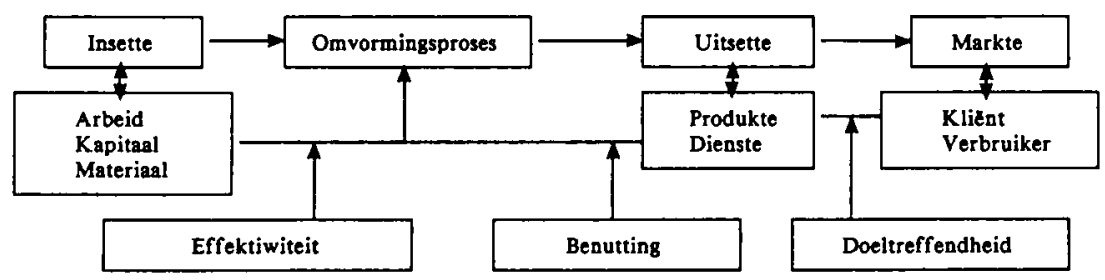

Bron: Oorgeneem en aangepas uit Smuts (1990:B3) en Presidentsraad (1989:7)

Produktiwiteit word uit 'n bedryfsekonomiese oogpunt beskryf as die verhouding tussen die uitset wat verdien word en die kapitaal en/of arbeid wat as insette in die proses gebruik word. By die praktiese toepassing van produktiwiteitsmeting is dit gebruiklik om die verwantskap tussen die uitset en die inset van 'n enkele produksiefaktor, hetsy grond, kapitaal of arbeid te bereken. So 'n berekening staan dan bekend as gedeeltelike of afgeleide produktiwiteit. Volgens die Nasionale Produktiwiteitsinstituut (NPI, 1988:7) word produktiwiteit soos volg bereken:
Produktiwiteit
kapitaal + arbeid + energie + grondstof (insette)

\section{Uitset}


Dit is duidelik dat die meeste literatuur die klem laat val op arbeidsproduktiwiteit en vir die doel van hierdie artikel sal deurgaans na arbeidsproduktiwiteit verwys word. Die rede hiervoor is dat kapitaal en grondstowwe op sigself nie iets kan produseer nie. Arbeid is nodig om die produksieproses te aktiveer. Arbeid speel dus 'n sentrale rol. 'n Tweede rede wat aangevoer kan word, is dat arbeidsproduktiwiteit die fundamentele strewe van mense, naamlik ' $n$ verhoging in lewenspeil, in ' $n$ groot mate bepaal. Dit is net gewoon nie moontlik om die verbruik per persoon (lewenspeil) te verhoog sonder 'n ooreenstemmende toename in die produksie per persoon nie. Die grootste probleem in die pogings om produktiwiteit in die RSA te verbeter, lê egter in die samestelling van die arbeidsmag. Dit word algemeen aanvaar dat die verskillende bevolkingsgroepe waruit die arbeidsmag saamgestel is, duidelik deur verskillende faktore gemotiveer word. Daarbenewens kompliseer die verskillende taalgroepe die situasie nog verder (Van Niekerk, 1981:33). Hierdie situasie op sigself vereis deeglike navorsing en plaas addisionele druk op opvoeders en opleiers, terwyl die getal en kwaliteit van opvoeders en opleiers beperk is.

Waar winste nog die ekonomiese regverdiging vir die bestaan van die onderneming is, is die volgende model van toepassing op enige onderneming waarvan die resultate deur mense bepaal word:

Opleiding $=$ Doeltreffendheid $=$ Effektiwiteit $=$ Produktiwiteit $=$ Winste

Uit 'n bestuursoogpunt reflekteer produktiwiteit die sukses of mislukking in die vervaardiging van goedere en dienste. Produktiwiteit beteken dus om 'n tak op die beste moontlike manier te verrig. Dit geld vir die volgende vlakke: individu, groepe en die onderneming as 'n geheel. Figuur 3 dui die drie vlakke van produktiwiteit in die onderneming aan: 
Figuur 3

Drie vlakke van produktiwiteit

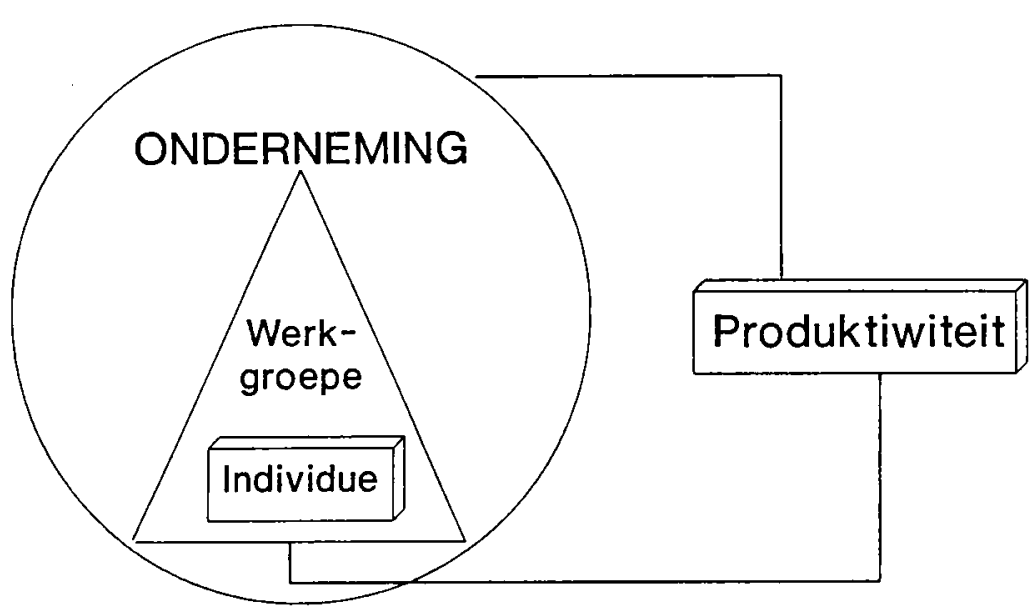

Bron: Oorgeneem uit Schemerhorn (1986:16) en Adam et al. (1981:1 en 2).

Hoë produktiwiteit vereis meer toepaslike tegnologie en hoogs opgeleide en vaardige werkers. Produktiwiteit vereis kreatiwiteit, gekombineer met werkstevredenheid, veiligheid en die geestesgesondheid van die werker.

Vervolgens enkele kort opmerkings oor produktiwiteit, kwaliteit en wins. Adam et al. (1981:12) maak die volgende stelling: "... a significant part of any productivity equation is quality. There is no economic value in increased output levels if the increase is offset by lower quality." Die kwaliteit waarna bogenoemde skrywer verwys, het duidelik te make met die mate waarin 'n produk of diens voldoen aan die voorafgestelde standaarde wat reeds voor produksie bepaal is (Presidentsraad, 1989:11 \& 12). Hierdie standaarde is verwant aan die wesenseienskappe wat die produk of diens se waarde in die mark moet hê, ten einde bepaalde behoeftes te bevredig.

Kwaliteit word altyd beïnvloed deur die gedrag van die werker in die werkplek, die ondernemingsbeleid en bepaalde tegnologiese faktore soos die ouderdom van die 
toerusting en masjinerie wat gebruik word asook die kwaliteit van onder andere die rumateriaal wat as inset gebruik word. In dieselfde konteks verwys Schemerhorn (1986:18) na die "... quality of working life ... as an indicator of the overall quality of human experience in the workplace".

Ten einde produktiwiteit en kwaliteit van produkte en dienste te bewerkstellig, is dit afgesien van 'n totale gehaltebeheer (TGB), die bestuur se taak om die kwaliteit van werksomstandighede op so 'n vlak te stel en te handhaaf dat dit wel moontlik is om hoe produktiwiteit en kwaliteit te bereik (Presidentsraad, 1989:250). Dit kan alleen bereik word deur die sogenaamde QWL-programme (Quality of Work Life Programs) soos dit deur Schemerhorn (1986:18) en Aft (1983:351) bespreek word. Die QWL-program vereis in die eerste plek ' $n$ herdefiniëring van die tradisionele gesagsdraer-ondergeskikte, werkgewer-werknemer en selfs bestuur-vakunie-verhoudings. Daar moet wegbeweeg word van die gedagte van 'ons teen hulle' - maar eerder 'ons gesamentlik' om die probleme van produktiwiteit en kwaliteit aan te pak. Die gedagte van gemeenskaplike belange moet nagestreef word en deelnemende bestuur moet tot sy volle konsekwensies deurgevoer word. Dan alleen kan die skeptisisme rondom so 'n program uit die weg geruim word. Die verbetering van produktiwiteit en kwaliteit word dan logiese neweprodukte van die QWL-program.

Produktiwiteit en winsgewendheid is nie sinoniem nie, behalwe dat daar tog 'n baie sterk verband tussen die twee begrippe bestaan. As produktiwiteit verhoog, sal die winsgewendheid van die onderneming ook verhoog, maar dit is tog moontlik dat die een verhoog terwyl die ander in die proses laag bly of selfs verder verlaag. Verhoogde produktiwiteit en dalende winste mag wel ' $n$ aanduiding wees van 'n tegnologiesvooruitstrewende onderneming in 'n beperkte mark. Die verhoogde produktiwiteit stel die onderneming in staat om in die mark mee te ding. Die teenoorgestelde situasie dalende produktiwiteit en stygende winste - is 'n uiters delikate situasie. Dit beteken dat insette ondoeltreffend benut word: die onderneming word gesus met die veronderstelling dat dit suksesvol is terwyl dit inderwaarheid inflasionisties is en gevoelig raak vir mededinging in die mark. Inflasie word te dikwels as 'n agtergrondskwessie gesien. Alhoewel inflasie nie produktiwiteitsgroei voorkom nie, trek dit tog beleidmakers (aldus bestuur) se aandag van produktiwiteitsverbetering af. Bestuurders bepaal hulle dan tot korttermynplanne ten einde te oorleef, terwyl die verbetering van produktiwiteit na langtermynbeplanning verskuif word (Presidentsraad, 1989:223)

Dit is belangrik dat produktiwiteit in die finansiële jaarstate van maatskappye weerspieël moet word. Indien die onderneming sy resultate van jaar tot jaar vergelyk, sal veranderings in die winsposisie gereflekteer word in 'n verandering in die produktiwiteit. Dit neem egter nie weg dat die verhoging van produktiwiteit sterk beïnvloed word deur psigologiese faktore nie. Ten einde die psigologiese faktore te omlyn, word 
arbeid as produksiefaktor en gevolglik ook as arbeidsproduktiwiteit bekyk.

\section{ARBEID EN ARBEIDSPRODUKTTWITEIT}

\subsection{Die sinvolheid van arbeid}

Gesien in die lig van stygende arbeidseenheidskoste, die sogenaamde psigose van loonverhogings waarin die hedendaagse mens beland het en die faktore wat 'n invloed op hoofsaaklik arbeidsproduktiwiteit uitoefen, is dit die aangewese tyd om weer te besin oor die doel of sinvolheid van arbeid. Nie alleen bestuur nie, maar elke individuele werker het die verantwoordelikheid om introspeksie te doen.

As vertrekpunt word daar aansluiting gevind by Brown (1986:187): "Work is an essential part of a man's life since it is that aspect of his life which gives him status and binds him to society. Work is a social entity." Die sin van arbeid kan nie vanuit homself bepaal word nie. Arbeid is nie 'n doel op sigself nie, maar moet in die groter verband van die kultuuropdrag van God aan die mens gesien word (Duvenage, 1983:244). Arbeid is deel van die roeping van die mens waarin sy diensbaarheid aan God en sy medemens tot uiting kom. Hieruit kan afgelei word dat die beroepsarbeid van die mens drieledig is:

- Die primêre doel is verantwoording teenoor God (religieuse oogpunt).

- Die persoonlike doel is die instandhouding van die lewe; die vervulling van die elementêre lewensbehoeftes (ekonomiese oogpunt).

- Die sosiale doel is die diens wat dit lewer in die samelewing; dan word arbeid 'n middel tot diensbaarheid (psigologiese oogpunt) (Duvenage, 1983:244 en Pietersen, 1990:180).

Wanneer iemand dan besef dat hy/sy geroep is met sy/haar besondere gawes en talente, gee dit stimulus om beroepsarbeid met volle oorgawe en verantwoordelikheid te doen. Sodanige instelling is gesetel in die aktiewe element van roepingsvervulling (Duvenage, 1983:248), naamlik die konsensieuse getrouheid in arbeid, die lojaliteit teenoor die werkgewer, die integriteit in optrede binne werksverband, en die ywer om volle bekwaamheid te bereik wat tot uiting kom in die bereiking van arbeidsvreugde. Hierdie fasette hou verband met die materiële en psigologiese omstandighede waaronder arbeid verrig word. 


\subsection{Arbeid: 'n werklikheid tot geestelike en sosiale roeping}

Die seën van arbeid lê in die feit dat dit die mens ten diepste bind aan die konkrete nood van die naaste - iets wat dan uitgroei tot konkrete naasteliefde. Sodoende word arbeid 'n sosiale roeping tot voordeel van die medemens.

Die geestelike roeping lê daarin dat elke arbeider selfdissipline moet toepas, integriteit moet openbaar in alles wat verrig word, die noodsaak moet besef om arbeid te kwalifiseer as roeping van Godsweë ("alles wat jou hand vind om te doen, doen dit met mag" Prediker 9:10) en te waak teen arbeidsverafgoding aan die een kant en arbeidsdevaluasie aan die ander kant is noodsaaklik. Arbeidsverafgoding en arbeidsdevaluasie moet vermy word, want die arbeid is vir die mens gemaak, nie die mens vir die arbeid nie (Duvenage, s.j.:7 en 8).

\subsection{Kwantifiseerbare en nie-kwantifiseerbare beloning van arbeid}

"Quite generally it can be debated whether satisfaction with one's job and its surroundings leads to productivity or whether productivity leads to satisfaction (sense of achievement) and/or higher earnings" (Brown, 1986:324). Duvenage (1983:249) het die volgende hieroor te sê: "Wanneer die arbeid losgemaak word van die mens wat die arbeid verrig en dan as merkwaardig beskou word, word dit heeltemal aan die spel van vraag en aanbod prysgegee." Dan verloor arbeid sy betekenis as roeping en word die objektiewe sinvolheid gedevalueer.

Die uitgangspunt in die beloning van die arbeider behoort tweeledig te wees:

- Beloon volgens behoefte - 'n regverdige loon volgens behoefte en 'n loon volgens prestasie.

- Hoër produktiwiteit behoort met 'n hoër loon vergoed te word.

Dit moet onthou word dat die loon ' $n$ middel is waardeur die mens al die fasette van sy roeping kan vervul. Dit gaan in wese om die toepassing van 'n billike beloningstelsel wat aan die eise van genoegsaamheid, gelykheid (gelyke betaling vir gelyke werk), sekuriteit en aanvaarbaarheid behoort te voldoen.

Wat die nie-kwantifiseerbare beloning betref, is dit deel van die dienskontrak, ook bekend as die 'sielkundige kontrak' (Pietersen, 1990:186). Verbind met Sutermeister se model (kyk afdeling 3.4) sou dit die wysiging van sosiale en tegniese aspekte van die werkplek met die oog op verryking van die inhoud van die werk inhou. Die heront- 
werp van werk is van strategiese belang in die strewe na hoër produktiwiteit. By 'n gebrek aan nie-kwantifiseerbare beloning is die gevaar dat werkvervreemding kan intree wat uiteindelik tot self-vervreemding kan lei. Kwantifiseerbare en nie-kwantifiseerbare beloning mag geensins 'n gevoel van magteloosheid of betekenisloosheid by die werker laat nie. Om dit te verhoed, moet bestuur die nodige meganismes en werkomgewing skep ten einde die sinvolheid van arbeid te beklemtoon.

\title{
3.4 Arbeidsproduktiwiteit
}

Die feit dat Suid-Afrika armer word is nie aanvaarbaar nie, want dit laat ons sonder 'n basis vir die oplossing van ons politieke probleme (Visser, 1990:B5). Individuele ondernemers sal hul produktiwiteit moet verhoog. Hoe meer individuele ondernemings produktiwiteit kan verhoog, hoe groter is die uitwerking op die totale ekonomie en hoe groter is die uitwerking op die welvaart van die land en sy mense (Presidentsraad, 1989:5).

Visser (1990:B5) is van mening dat die manier waarop bestuur produktiwiteitsverhoging aan die werkers kommunikeer die kern van die probleem is.

\begin{abstract}
Hoewel baie mensc oor hoër produktiwiteit praat, is daar nie allerweë 'n besef wat dit eintlik behels nie. Opnames het gewys dat die meeste werknemers nog nie die boodskap dat hoër produktiwiteit juis vir hulte groter loonvoordele inhou, ontvang het nie. Werkgewers dra dit nie so aan hulle oor nie.
\end{abstract}

Voortdurende aansprake op hoër lone het Suid-Afrikaanse ondernemings in 'n loonpsigose laat beland, waaruit nie maklik losgekom gaan word nie (Kotze, 1984:114). Dit is 'n duidelike bewys dat 'n hoër lewenspeil nooit gekoop kan word nie. Reële lone kan alleen verhoog word deur'n verhoging in produktiwiteit.

Selfs die onderhandeling met georganiseerde arbeid sal meer doeltreffend aangepak moet word. Onderhandelinge wat maande lank uitgerek word, is net nie meer aanvaarbaar nie. 'n Vinniger onderhandelingsproses is die wagwoord. Die punt is duidelik bereik waar georganiseerde arbeid hom op arbeidskwessies eerder as op politieke kwessies moet toespits. Ondoeltreffendheid en lae produktiwiteit wat deur hoë afwesigheid veroorsaak word, kan nie bekostig word nie (Pretorius, 1991:29). Brown (1986:312) sê in dié verband:

Management faces the problem of how to elicit commitment from their workforce so as to maintain or increase productivity and keep the costs incurred through labour turnover or absenteeism at a low level.

Visser (1990:B7) wys op 'n verdere onrusbarende verskynsel op die arbeidsterrein. Die 
arbeidseenheidskoste in die fabriekswese, aangedui in rand, word sedert 1966 noukeurig gevolg deur die kromme van die verbruikersprysindeks. Die uurlikse verdienste in die Suid-Afrikaanse fabriekswese het naas Suid-Korea sedert 1973 die sterkste toename getoon - veel sterker byvoorbeeld as dié van Brittanje, Amerika, Japan en WesDuitsland. Terwyl arbeidsproduktiwiteit in dié tyd in Suid-Korea met sowat 300\% toegeneem het, het dit in Suid-Afrika met slegs $30 \%$ gestyg.

'n Verdere faktor wat nie uit die oog verloor moet word nie, is dat ekonomiese groei nodig is om werkgeleenthede te skep. Vanaf 1980 tot 1988 is 161400 bykomende werkgeleenthede in Suid-Afrika geskep. Werkverskaffing vir swart mense in sektore buite die landbou was in 1986 feitlik op dieselfde vlak as in 1976: dit beteken dat 10 jaar se bevolkingsgroei nie in diens geneem kon word nie (Visser, 1990:B5).

Die Komitee vir Ekonomiese Aangeleenthede (Presidentsraad, 1989:29) asook Presidentsraad (1983:25-27) sê dat die langtermynaard van die probleem geillustreer word deur die feit dat die nuwe toetredes tot die arbeidsmag van die jaar 2000 reeds gebore is. Dit is ook bekend dat die bevolking neig om al hoe jonger te word, met 'n klein persentasie wat werklik ekonomies aktief is. Met toenemende verstedeliking sal die bevolking in ' $n$ toenemende mate in stedelike gebiede van werkgeleenthede voorsien moet word. Die Komitee (Presidentsraad, 1989:29) het dan ook in dié verband aanbeveel dat die ekonomiese doelwit van volle werkverskaffing van besondere belang is vir 'n ontwikkelende ekonomie soos dié van Suid-Afrika.

Mense is geneig om van mekaar te verskil op grond van hul agtergrond, ervaring en bepaalde definisie van die begrip produktiwiteit. Produktiwiteit ontlok duidelik emosionele en gepolariseerde reaksies van vakunies, werkers, bestuur, aandeelhouers en verbruikers (klante). Juis vanweë groot meningsverskil is dit belangrik om vas te stel watter faktore arbeidsproduktiwiteit beïnvloed.

In wese bestaan daar baie min modelle om die onderlinge verbande tussen die faktore wat produktiwiteit beïnvloed te verduidelik. Sutermeister (1969:(i)) bied 'n sistematies beskrywende model aan om die hierdie verbande weer te gee (bekend as Sutermeister se model). 
Figuur 4

Sutermeister se model

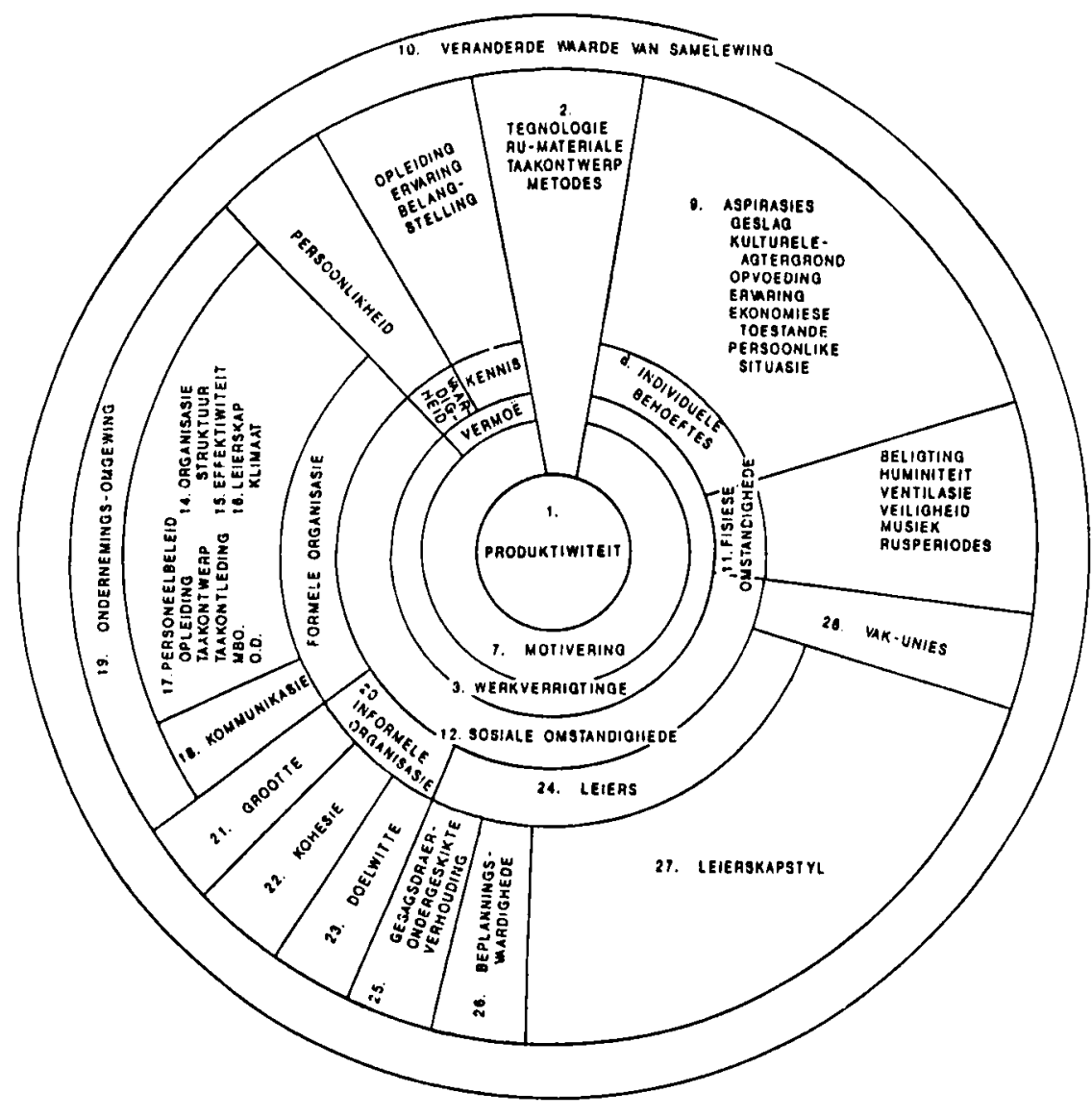

Bron: Oorgeneem en aangepas uit Sutermeister (1969:(i)). 
Uit figuur 4 blyk dit dat Sutermeister se model 'n reeks konsentriese sirkels verteenwoordig, en die konsentriese sirkels nader aan die middelpunt het ook 'n groter invloed op produktiwiteit. Die belangrikste bevinding wat Adam, et al. (1981:125) maak is die volgende:

Motivation is a function of ability and employees' job performance. Ability in turn, is composed of skill and knowledge, whereas job performance is influenced by the individuals' needs and the physical and social conditions of the workplace.

(Dieselfde bewering is reeds gemaak in die inleiding van hierdie artikel.) Verdere interafhanklikhede kan afgelei word deur na die verskillende segmente van die model te kyk in die volgorde wat hulle genommer is. Die bedoeling is om slegs aan die leser 'n aanduiding te gee van watter faktore 'n direkte en indirekte invloed op produktiwiteit kan hê.

Daar is baie alternatiewe maniere om produktiwiteit te verhoog. Aft (1983:8) sê: "... clearly the human factor is one of the most important aspects of increasing productive output. ... However, people solutions are not the only ones available". Weihrich (1986:11) sê: "There is not one best approach to productivity improvement."

Dit is duidelik dat die Sutermeister-benadering sterk op die menslike faktor en die menslike aard konsentreer om produktiwiteitsverhoging in die individuele onderneming te bewerkstellig. Sou hiermee volstaan word, is die benadering eensydig en kan kritiek teen die sogenaamde eensydigheid uitgespreek word. Uit 'n bestuurswetenskaplike oogpunt is die ideaal 'n balans tussen taak- en mensoriëntasie. Van Niekerk (1981:32) daarenteen beklemtoon die volgende produktiwiteitsverhogingsfaktore: 
TABEL 1

PRODUKTTWITEITSVERHOGINGSFAKTORE/TEGNIEKE

A. EKSTERNE PRODUKTIWTTEITSVERHOGINGSFAKTORE/TEGNIEKE

1. Die gesindheid van werkers en bestuur teenoor produktiwiteitsverboging

2 Ekonomicse en omgewingsproduktwiteitsverhogingsfaktore

(a) Die grootte van die mark

(c) Die mobiliteit van produksiefaktore

(d) Die kwaliteit en beskikbaarheid van grondstowwe

e) Die beskikbaarheid van kapitaal en krediet

(f) Die belastingstruktuur

(g) Beskikbare opleidingsfasiliteite

(h) Navorsing en uitruil van inligting

(i) Tegnologese innovasie en meganisasie

(j) Vestigingsplekvoordele

\section{B. INTERNE PRODUKTIWITEITSVERHOGINGSTEGNIEKE}

1. Fabrieksuitleg masjinerie en toerusting

(a) Die boeveelheid kapitaal per werker

(b) Materiaalhantering

(c) Die onderhoud van masjinerie en toerusting

(d) Fabrieksuitleg

2. Kasteberekening en kosteverminderingstegnieke

(a) Kostebeheer

(b) Begrotings en begrotingsbeheer

(c) Geleentheidskoste-analise

(d) Inkrementcle koste-analise

(e) Gelykbrekingsanalise

(f) Uitsonderingsbeheer

(g) Georganiseerde kosteverminderingsprogramme

(b) Verdiskonteerde kontantvloeiberekenings

3. Organisasie, beplanning en beheer van produksic

(a) Produksiebeplanning en beheer

(b) Tipisasie, standaardisasie en spesialisasie

(c) Werkstudie

(d) Organisasie- en metodestudie

(e) Voorraadbeheer/Ekonomiese voorraad

(f) Waarde-analise

(g) Ander tegnieke soos verrigtingsnavorsing, steekproeftrekking, simulasie, toustaanteorieë, Pert, ensovoorts

4. Personeelbelcid

(a) Samewerking tussen bestuur en werkers

(b) Keuring en plasing van werkers

(c) Beroepsopleiding

(d) Taakanalise, personcelwaardering en -bevordering

(e) Toesighouding en dissipline

(f) Loonaansporing- en winsdelingstelsels

g) Werksomstandighede en welsynsdienstc

(g) Arbeidsmetodes

(i) Lengte van werksdag

(j) Aantal skofte

Bron: Oorgeneem en aangepas uit Van Niekerk (1981:32). 
Bogenoemde uiteensetting moet egter met Sutermeister se model saamgelees word, ten einde 'n duidelike beeld te kry van die magdom faktore wat ' $n$ invloed kan hê op produktiwiteitsverhoging.

Die voorstellings van sowel Sutermeister as van Van Niekerk beklemtoon egter nie die noodsaaklikheid van strategiese beplanning om produktiwiteitsverhoging te bewerkstellig nie. Weihrich (1986:20-26) sê dat produktiwiteitsverbetering bewerkstellig kan word deur sinvolle strategiese beplanning en 'n doelwitbestuursprogram. Die bepaling van doelstellings en doelwitte wat nie alleen meetbaar is nie, maar ook realisties is, is nodig om produktiwiteit te meet. Nie alleen moet doelstellings en doelwitte duidelik geformuleer word nie, maar prioriteite moet bepaal word op grond van elke doelstelling en doelwit se relatiewe belangrikheid. Die doelstellings en doelwitte word dan standaarde waarteen toekomstige optrede en resultate gemeet word. Die beplanning wat op die doelwitstelling volg, dui dan in detail aan hoe hierdie standaafde/mikpunte bereik gaan word.

Ander programme, wat aanvullend tot doelwitbestuur gebruik kan word om produktiwiteit te verhoog is:

* Mannekragbeplanning

* Bestuursontwikkelingsprogramme

* Loopbaanbeplanning

* Nul-basisbegroting

* Organisasie-ontwikkeling (OD)

* Gehaltekringe

Bogenoemde is maar enkele aspekte wat spesiale aandag verdien. Baie kan nog gesê word oor veral moontlike aansporingstelsels wat gebruik kan word ter wille van produktiwiteitsverbetering (Botha, 1980:26). Aansporingstelsels word beskou as tasbare dryfvere wat die werker aanspoor om doelwitte te bereik. Ten einde die werker in staat te stel om 'n gestelde doelwit soos produktiwiteitsverbetering te bereik, is opleiding en heropleiding in die werksituasie van die uiterste belang.

In tabel 1 is die aspek van opleiding aangeraak. Aandag gaan kortliks geskenk word aan die noodsaaklikheid van opleiding vir produktiwiteitsverbetering. 


\section{OPLEIDING EN HEROPLEIDING TOT PRODUKTIWITEITSINGESTELD- HEID}

Suid-Afrikaanse maatskappye bestee jaarliks miljoene rande aan bestuursopleiding en personeelontwikkeling, maar nogtans bly produktiwiteit, wat een van die laagste ter wêreld is, skokkend. Dit is in 'n groot mate te wyte aan gebrekkige opleidingsmetodes en ook dat werknemers bloot in hul werksituasie beoordeel word sonder inagneming van die onderskeie fasette van hul lewe (Anon, 1989:9). Sutermeister (1969:442) stel dit soos volg:

In any event, it is commonly hypothesized that, whatever the causes, increased satisfaction makes workers more motivated to produce. Given this condition, it should follow that increased productivity can be attained by increasing worker satisfaction.

Opleiding moet sodanig gestruktureerd wees dat dit nie alleen die werker se kennis en vaardigheidsvlak verhoog nie maar inderdaad lei tot groter werksbevrediging. Bestuur kan wel die omstandighede, die klimaat skep, om werkers te motiveer om 'n positiewe ingesteldheid te verwerf. Sou die klimaat 'reg' wees, dan sal produktiwiteit verhoog. In baie gevalle weet bestuur wat skort, maar versuim om daadwerklik iets daaraan te doen met die uiteindelike gevolg dat produktiwiteit laag bly en die arbeidsomset verhoog. 'n Ontleding van tendense in Suid-Afrika toon dat bestuur wegskram van 'n individu se behoeftes, in plaas daarvan dat hy hom daarmee vereenselwig (Anon, 1989:9). As dit nie gedoen word nie, beteken dit dat die werker slegs 'n taak verrig, in plaas dat dit uitmuntend en suksesvol verrig word.

Navorsing toon dat meer as die helfte van alle produktiwiteitsgroei voortspruit uit vooruitgang in kennis, dit wil sê om die geskikte tegnologie te kry en die gehalte van arbeid op te gradeer deur opleiding en ontwikkeling (Kendrick \& Grossman, 1980:16). Die Komitee vir Ekonomiese Aangeleenthede (Presidentsraad, 1989:200) stel dit duidelik dat ontoereikende opleiding beskou word as een van die belangrikste faktore wat produktiwiteitsgroei belemmer.

By die stel van opleidings- en ontwikkelingsdoelwitte, sonder oorlegpleging met die werkerskorps, sal die vereiste produktiwiteitsvlakke moeilik behaal word. Aan die ander kant, waar deelnemende bestuur tesame met voldoende opleiding gebruik is, het die werkers sonder uitsondering baie gunstig gereageer en het produktiwiteit met tot $50 \%$ en selfs meer toegeneem (Presidentsraad, 1989:205). Deeglike ontledings van opleidingsbehoeftes, met inagneming van die bekwaamhede wat werkers moet verwerf om beter te presteer, word as noodsaaklik beskou.

Wat bestuursopleiding betref, moet alle bestuurders sodanig opgelei word om te besef dat produktiwiteit 'n holistiese konsep is en dat hulle dienooreenkomstig moet bestuur. 
Opleiding tot produktiwiteitsingesteldheid kan ten slotte na analogie van 'n orkes begryp word (Steyn, 1988:7). Binne die onderneming is die bestuurder die dirigent wat vanaf die bladmusiek werk. Hierdie bladmusiek is ontwikkel deur ' $n$ verskeidenheid produktiwiteitsbelanghebbendes. Die bestuurder ken aan elke speler ' $n$ rol in die orkes toe volgens sy/haar spesifieke vermoë, aanleg en belangstelling. Terselfdertyd koördineer hy/sy die verskillende groepe instrumente in die orkes. Harmonie lei tot die voortbring van 'n suiwer melodie. Dié uitdaging eis van alle belanghebbendes om binne 'n vennootskap hiervan erns te maak.

\section{SAMEVATTING EN GEVOLGTREKKINGS}

\subsection{GEVOLGTREKKINGS}

Wat hier volg, is nie 'n getroue weergawe van die voorafgaande nie; dit lig bloot 'n aantal van die belangrikste gevolgtrekkings uit sonder om afbreuk te doen aan die belangrikheid van enige van die aangeleenthede wat in die artikel bespreek is.

* Dit word duidelik besef dat die uitwerking van produktiwiteit elke menslike aktiwiteit en elke aspek van 'n land se ekonomiese, maatskaplike en politieke lewe raak.

- Dit is hoogs wenslik dat die bestuur van die onderneming produktiwiteitsverbetering moet aanvaar as die belangrikste enkele langtermyndoelwit. Deur die resultate wat daardeur bereik word, kom alle ander doelwitte 'n stap nader aan verwesenliking.

- Dit is die taak van bestuur om produktiwiteitsverbetering te inisieer. Dit is daardie groep mense wat produktiwiteit moet verstaan en moet weet hoe die deurlopende verbetering van produktiwiteit hulle persoonlike en organisasiedoelwitte kan verwesenlik. Al is produktiwiteit egter bestuursgedrewe, sal weinig sukses behaal word tensy die totale werkerskorps daartoe verbind is. Deelnemende bestuur bevorder nie alleen 'n positiewe bestuur-werkersverhouding nie, maar sal produktiwiteit, kwaliteit en winsgewendheid bevorder. 'n Produktiwiteitsplan moet sowel die bestuur as die werkers toerus met 'n ywer vir produktiwiteit.

* Bestuur moet die nodige infrastruktuur daarstel vir opleiding en heropleiding in gehalte- en produktiwiteitsverwante vakke. Gehalte en produktiwiteit is onlosmaaklik aan mekaar verbonde. Sowel produktiwiteit as gehalte is holisties van aard; daarom moet gehalte (kwaliteit) 'n integrerende deel van die onderneming se produktiwiteitsverbeteringsprogram wees. 
- As deel van die opleidingstaak van bestuur is dit die aangewese tyd om opnuut te besin oor die sinvolheid van arbeid. Nie alleen bestuur nie, maar elke individuele werker het die verantwoordelikheid om introspeksie te doen. Hoër produktiwiteit behoort met 'n hoër loon vergoed te word. Bestuur moet produktiwiteitsverhoging aan die werkers kommunikeer. 'n Hoër lewenspeil kan nie gekoop word nie.

* Uit ' $n$ bestuurswetenskaplike oogpunt is die ideaal in die soeke na produktiwiteitsverhogingsfaktore dié van balans tussen taak- en mensoriëntasie.

* Bestuur moet die waarde en noodsaaklikheid van strategiese bestuur en as sodanig strategiese beplanning, doelwitbestuur en deelnemende bestuur besef ten einde produktiwiteitsverhoging te bewerkstellig. Bestuursopleiding moet sodanig gestruktureer word dat strategiese denke en die bestuur van verandering verdiskonteer word. Produktiwiteit is 'n holisitese konsep en dit moet dienooreenkomstig bestuur word.

Bogenoemde gevolgtrekkings moet gesien word teen die agtergrond van 'n nasionale bewustheidsveldtog wat alreeds in 1989 deur die Presidentsraad (Presidentsraad, 1989:262) in vooruitsig gestel is en waarna daar met groot verwagting uitgesien word.

\subsection{Samevatting}

Produktiwiteit behels die optimum kombinasie en maksimum benutting van alle produksiefaktore. Daadwerklike produktiwiteitsverbeteringsprogramme moet in elke onderneming toegepas word en moet alle vlakke van werkers betrek. Hierbenewens moet bestuur volle samewerking verleen aan so 'n program en die geslaagdheid daarvan moet gereeld op een of ander wyse gemeet word.

Werkgewers en werknemers behoort 'n vennootskap te vorm by die opstel van enige produktiwiteitsverbeteringsprogram. Indien 'n regverdige verdeling plaasvind van die voordele wat uit produktiwiteit voortspruit, kan vakunies 'n positiewe bydrae tot produktiwiteitsverhoging lewer. Nie alleenlik kan hulle ' $n$ bydrae tot arbeidsvrede lewer nie, maar kan hulle ook swak bestuur uitwys. So 'n gesamentlike aksieprogram is nodig om die verhoging van veral arbeidsproduktiwiteit te bewerkstellig. Die belangstelling en absolute verbintenis van die topbestuur is noodsaaklik vir die sukses van enige produktiwiteitsprogram.

In die strewe na produktiwiteitsverbetering moet onthou word dat dit mense is wat resultate behaal - hulle vra normaalweg om as mense en individue behandel te word. Die werker se waarde kan slegs verhoog word deur sy/haar potensiaal te ontwikkel. 
Die kapasiteit hiervoor is onbeperk. Dit is alleen wanneer opleidings- en ontwikkelingsbehoeftes akkuraat geïdentifiseer word, en die nodige opleiding dan verskaf word om dié behoeftes te bevredig, dat produktiwiteit werklik verbeter kan word.

Die oorkoepelende doelwit van produktiwiteitsverbetering is om rykdom te skep en op 'n billike wyse daarin te deel. Dit impliseer nie suiwer materialisme nie; bloot dat elke individu sy/haar eie en die land se geestelike, kulturele en politieke doelwitte sal kan verwesenlik.

Hoewel regerings baie kan doen om produktiwiteit in die breëre sin te verhoog deur die regte klimaat daarvoor te skep en op regionale vlak korrek te beplan, berus die verhoging van produktiwiteit op die daadwerklike pogings van individuele ondernemings. As hoë produktiwiteit in die toekoms behaal wil word, sal bestuur die leiding moet neem.

Wright (1987:34) stel die ideaal soos volg:

It may not be 'Japanese', it may not be 'textbook', it may not have ever been done before - but it will be an effective and rewarding undertaking.

Produktiwiteit bly die hoeksteen van 'n gesonde, vooruitstrewende en welvarende gemeenskap.

\section{BIBLIOGRAFIE}

ADAM, E.E., HERSHAUER, J.C. \& RUCH, W.A. 1981. Productivity and quality. Measurement as a basis for improvement. New Jersey : Prentice-Hall

AFT, L.L. 1983. Productivity measurement and improvement. Virginia : Reston Publishing Co.

ANON. 1989. Swak opleiding lei tot lae produksie. Die Transvaler: 9, Julie 17

BOTHA, F. 1980. Verhoog produktiwiteit deur motivering. Volkshandel, 41(8):25 en 26. Oktober.

BROWN, JA. C. 1986. The social psychology of industry. England : Penguin Books.

DUVENAGE, B. 1983. Roeping en Wetenskap. Tweede hersiene uitgawe. Potchefstroom : PU vir CHO.

DUVENAGE, S.C.W. s.j. Die beplanning van werk en tyd vanuit 'n Calvinistiese visie. Instituut vir die Bevordering van Calvinisme. Potchefstroom : IRS / PU vir CHO. Studiestuk nr. 7.

KENDRICK, J.W. \& GROSSMAN, E.S. 1980. Productivity in the United States, trends and cycles. Baltimore/London : The John Hopkins University Press.

KOTZE, A. 1984. Produktiwiteit en gehaltekringe. (Lesing gelewer op 30 Oktober 1984 by die Nasionale Konvensie vir produktiwiteit en gehaltekringe, WNNR. Pretoria.

NASIONALE PRODUKTIWITEITSINSTITUUT. 1988. Productivity Focus. Pretoria. 76p.

PIETERSON, RJ. 1990. Die arbeider is sy loon werd. (In Venster op die sakewêreld: Perspektiewe op Bedryfsetick.) Potchefstroom : IRS / PU vir CHO

PRESIDENTSRAAD.

lyyk

SUID-AFRIKA (REPUBLIEK). 
PRETORIUS, B. 1991. Arbeid 'n deurslaggewende faktor, Finansies en Tegniek: 29. Jan. 11.

RANFTL, R.M. 1986. Seven keys to high productivity. Research Management: 11-18. SeptemberOktober.

SCHEMERHORN, J.R. 1986. Management for productivity. New York : John Wiley and Sons.

SMUTS, J. 1990. 'n Nuwe S.A. waarin almal wenners kan wees. Bylae tot Finansies en Tegniek: 38. Sept. 7.

STEYN, I.N. 1988. Opvoeding tot produktiwiteitsingesteldheid. (Lesing gelewer op 19 September 1988 by 'n simposium van die privaatsektorstigting.) Windhoek. 18p. (Ongepubliseer).

SUID-AFRIKA (REPUBLIEK). Verslag van die Wetenskap Komitee van die Presidentsraad oor demografiese tendense in Suid-Afrika. Kaapstad : Staatsdrukker. (PR 1/1983.)

SUID-AFRIKA (REPUBLIEK). Verslag van die Komitee vir Ekonomiese Aangeleenthede oor 'n strategie en aksieplan ter verbetering van produktiwiteit in die RSA. Kaapstad : Staatsdrukker. (PR 1/1989).

SUTERMEISTER, R.A. 1969. People and productivity: major factors affecting employees' job performance and productivity. New York : McGraw-Hill Book Company.

VAN NIEKERK, W. P. 1981. Produktiwiteit en werkstudie. Durban : Butterworth.

VISSER, J. 1990. Produktiwiteitsbewustheid dringend noodsaaklik. Bylae tot Finansies en Tegniek: B5B7. Sept. 7.

WEIHRICH, H. 1986. Management excellence. Productivity through MBO. New York : McGraw-Hill. WRIGHT, W. L. 1987. Overcoming barriers to productivity. Personnel Joumal: 34. February. 